\title{
INTERNAL FACTORS SUPPORTING BUSINESS AND TECHNOLOGICAL TRANSFORMATION IN THE CONTEXT OF INDUSTRY 4.0
}

\author{
Lucia KOHNOVÁ ${ }^{1}$, Ján PAPULA², Nikola SALAJOVÁ ${ }^{3}$ \\ Faculty of management Comenius University, Bratislava, Slovakia \\ E-mails: ${ }^{1}$ lucia.kohnova@fm.uniba.sk (corresponding author); ${ }^{2}$ jan.papula@fm.uniba.sk; \\ ${ }^{3}$ nikola.salajova@fm.uniba.sk
}

Received 17 January 2019; accepted 21 February 2019

\begin{abstract}
Radical changes resulting from the Fourth Industrial Revolution strongly affect industrialized European countries. In particular, due to the new technologies that are characteristic of Industry 4.0, it will be essential for companies to make the necessary changes and achieve competitiveness through the implementation of these technologies. In order for companies to be able to make radical changes and innovations, they need to secure all the supporting areas in their organization. This research paper is focused on comparison of companies from Slovakia, Czech Republic, Austria, Germany and Switzerland in the context of readiness for Industry 4.0. This research was part of a research project, while data were collected in the period of 2015-2016. We have analysed companies from selected countries based on 7 areas which are closely interconnected with the business transformation and technology transformation coming from Industry 4.0. The main analysed questions focused on areas such as employee education and training, organizational culture, strategy, or organizational processes, that will be most affected by radical changes in the environment. Research has highlighted the differences between countries as a result of long-standing cultural differences, but at the same time identified the unified influence of the ongoing global debate on the need for technological innovation. With Slovak and Czech companies being below stronger innovators in the maturity of education systems, we strongly advise considering partnering in education which can bring valuable information to businesses that want to take on the wave of innovation.
\end{abstract}

Keywords: Industry 4.0, business transformation, preparedness, technology, employee education, strategy.

JEL Classification: O33, M10.

\section{Introduction}

Technological change that is widely effecting the industrial sector is often spoken in the context of technologies such as Cybernetic-Physical System (CPS), Internet of Things (IoT), Internet od Services (IoS), Big Data, Smart Factory, Interoperability and so on (Dalenogare et al. 2018). Not just industrial enterprises, but all competing on the market are currently struggling with the question of what changes are needed to make them competitive, and how to make and implement the newest innovation in the most effective way. The Industry 4.0 concept is based on the ability of people, machines, devices, logistics systems and products to communicate and collaborate with each other. The connection of products, devices, people, increases the efficiency of production machines and equipment, reduces costs and saves resources. This intelligent monitoring and process transparency provides a constant insight into companies. Then can companies flexibly and quickly respond to changes in the marketplace (Berger 2014, Siemens 2016, KPMG 2016, Deloitte 2015, Ješko 2016, Industry4 2019). According to Kagermann et al. it is expected that the main benefits from adoption of Industry 4.0 components the organization will gain flexible manufacturing processes, will be able to analyze large amount of real time data and will improve the processes of strategic and operational decision making (Kagermann et al. 2013).

The main objective of this study was to analyze differences among companies from five European countries in the context of readiness for Industry 4.0 in seven selected areas. Using statistical test for analyzing significance of differences 
we were able to identify which countries are better prepared in each area. With a close analysis of companies from each country, we looked at the distribution of answers and were able to compare the behavior in each area. We have identified that main differences occur between Slovak and Czech companies compared to Austrian, German and Swiss companies, which also rank higher in innovation rankings than Slovak and Czech companies. Interestingly, Slovakia as a small and open economy, strongly economically linked to the German economy, achieves better ratings than the Czech sample mainly in ability to identify trends and respond to them as well as strategic alignment. While the availability of technologies and knowledge to develop new products / services is of high importance in all countries surveyed it draws more attention to the other areas, in which moderate innovators must improve in order to be able to compete on the future markets. The conclusions were based on results from comparative study, supported by the literature review. Research results and the main findings may serve managers from all companies that want to increase their innovativeness and competitiveness, mainly from less innovative countries. This study provides a unique insight in the topic of Industry 4.0, where we discuss the supporting areas that need to be secured in order to be able to implement the main changes that are discussed in the literature.

\section{Literature review}

For Industry 4.0 is characteristic vertical integration, horizontal integration, application of technology and accelerating through exponential technologies. Vertical integration means integration of intelligent manufacturing systems (intelligent factories, products, intelligent logistics, production, marketing, services) with customer orientation. Horizontal integration refers to integration through new global networks that create added value (integration of business partners and customers, new business models, cooperation with other countries). Application of technology is provided throughout the value chain, not only in the production process but also in the whole product life cycle. Accelerating through exponential technologies means that technologies will be able to apply massively on the market because their price will drop rapidly and power will grow (e.g. sensors) (Deloitte 2015). The concept of Industry 4.0 consists of many technologies that describe it. These technologies are Cybernetic-Physical System (CPS), Internet of Things (IoT), Internet of Services (IoS), Big Data, Smart Factory, Interoperability and so on. CPS means connection of physical and virtual world where computers and networks monitor and control physical processes with feedback. IoT combines physical facilities over the network and gathers data for decision-making. IoS provides services through the Internet. Services are offered with added value from different suppliers through various communication channels. Big Data is a collection of various data from all divisions of company, also data from outside. Smart Factory helping people and the machine to perform tasks by gathering information online (CPS communicates through IoT). We can determine the status of the facility, its position, and so on. When combining the elements together, it is Interoperability. It connects CPS, people and Smart factories, communicating through the IoT and IoS (Herčko and Štefánik 2015, Bohan 2016, Clearpath team 2018). A successful company applies Smart Factory principles to its organization. Concept of Smart factory means a system of operations and production systems that are interconnected and flexible. Systems are integrated to adapt to new demands. Smart factory combines manufacturing, information and communication technologies. These technologies are integrated across the supply chain of manufacturing. It's a paradise for efficiency, because there is no downtime, waste and systems have the ability to predict and adapt to changes in facilities. The company that runs Smart factory has better position in a competitive marketplace. The basic element of Smart factories is the data (Deloitte 2017, Clearpath Robotics 2018, Hessman 2013).

The arrival of the Fourth Industrial Revolution will cause also changes in the structure of professions and specialization of employees. Demand for employees performing routine activities will decrease. Routine activities will be replaced by machines. New claims bring new professions and specializations. It will be needed to develop digital processes for digital staffing. The success of the organization will depend on the skills of digitization workers. Companies will require data analytics capability and better organizational structure. According to some authors, five most required industrial IoT jobs for the next years will be: industrial data scientist, robot coordinator, IT/IoT solution architect, industrial computer engineer/programmer, industrial UI/UX designer (PWC 2016, Bendová 2018, Lueth 2015).

\section{Preparation for Industry 4.0}

According to a Cisco Systems survey conducted in April 2011, approximately 50 billion facilities will be connected to the Internet by 2020. It represents 6.58 facilities per person. Billions of them will be built into everyday necessities, from clothing to mobile phones and car parts (Pease 2013). Czech authors define 5 levels of digital forwardness. At the first level, there is a company that has an established information system for management of production and does not use internet. The company begins to consider digitizing processes, production, maintenance, product, but does not have a defined digital strategy. At the second level, companies have an interactive website, a software- driven business, automation, and are considering to build up a digital strategy. Multi-channel solutions (web, mobile, tablets, social networks), defined digital strategy and integrated 
automation (MES) are typical of the company's at the third level of digital forwardness. For the fourth level of digital forwardness is characteristic an integrative, multi-channel digital solution in the digital world. The company has a distributed and personalized digital strategy and integrated data architecture throughout the whole manufacturing chain. At the highest level, there are companies that have a digitization platform with online and off-line worlds in one integrated and economical unit. They apply the latest and most effective approaches (full automation, 3D press ...) through a cyber-physical system (Mařík et al. 2016).

Particular, the industrialized countries are mostly focused on the preparation for transformation of the industry. Germany is a country where Industry 4.0 term was first introduced. Several government institutions, research centers and companies (SAP, National Academy of Sciences and Engineering, German Research Center for Artificial Intelligence and so on) are involved in the implementation of Industry 4.0 in Germany. The fourth industrial revolution is also recognized in Slovakia. According to Lacko, Slovak companies focus in particular on increasing the efficiency and effectiveness of internal processes (Lacko 2018). Companies want to use technology primarily to save costs, increase competitiveness, replace lack of employees. Research shows, that $60 \%$ of companies have enough information and knowledge about Industry 4.0 (Lacko 2018). For Czech Republic is the industrial sector very important part of economy as well. The Czech Republic has one of the highest shares of industrial production per GDP among EU countries (approximately $32 \%$ GDP) (Alm et al. 2016), thus the preparation for the upcoming and ongoing changes is of high importance.

Preparation of businesses to adopt to changes coming from Industry 4.0 directly stems from the core of this revolution. In addition to implementation of new technologies, companies are also facing significant changes in strategy, education, processes, and the overall organizational culture that must be set up to support the introduction of many of these changes. While there is still a lack in research considering business transformation, it is already understood that this transformation is needed to take advantage of Industry 4.0's potential. According to Christensen (Christensen 2006), the fundamental challenge of these disruptive technologies is "a business model problem, not a technology problem". The business model may go through radical changes or incremental, which go hand in hand with transformation of its parts, such culture, education, strategy, processes etc. In all cases, top management must have a clear vision and commitment in order to create an environment where the digital culture will be in an acceptable form throughout the organization and employees will be willing to learn to work with new technologies (Dávideková et al. 2017, PWC 2016) Managers face the question how to face the future and how they will respond to the changes that are waiting for them. Change cannot be a threat to managers but a way for developing new opportunities. Classical approaches should be replaced by knowledge, knowledge capital. Managers need to know that innovations do not develop each other at the same time, but they blend together (Častorál 2010). It will be inevitable to optimize the educational infrastructure while Industry 4.0 technologies are adopted (Rüßmann et al. 2015). Not only from the point of view of general education systems, but also internal employee education and development. The integration of employee knowledge, not only internal but also external, is the way to achieve competitiveness (Kach et al. 2015, Stachová et al. 2019, Pajtinkova Bartakova et al. 2017). Knowledge networks, as a way of sharing knowledge, are built on involving external partners in the knowledge sharing process, whether they are universities, business partners, research institutions, suppliers, competitors etc. (Connell et al. 2014). Support of employee training by external subjects can significantly improve the knowledge gathering and sharing process (Moron and Taylor 2004). It is indisputable, that the need for new concepts for managing of information and business administration will be stressing for more cooperation and knowledge sharing aspects (Prause 2015).

Whether the overall education system includes only internal forms of education and development, or even external partners, it is an important area - an internal factor of the organization that will affect how fast and efficient companies adapt to Industry 4.0. However, in order to exploit the potential of human capital, it is imperative that an organizational culture is set up to promote the sharing of knowledge within the enterprise and beyond its borders as well as to encourage the innovativeness of its employees. The transition to Industry 4.0 is not just about implementing new technologies and using them for a more efficient or cheaper processes in business, but more about taking advantage of opportunities for business innovation, its processes, products, and so on. In order for enterprises to be able to defeat the competitors with innovation, it will be important to direct the resource utilization strategy (human, material, financial) to activity aimed at achieving new strategic positions and goals. In the current scholar literature, there is a very detailed discussion of the technologies that are being developed within Industry 4.0 and on the possibilities of their use mainly in industry, but the full use of their potential requires changes in the internal settings of the enterprises, which has not been deeply discussed yet.

\section{Materials and methods}

The research in this article is focused on the preparedness of enterprises for the Fourth Industrial Revolution. The survey was conducted through an electronic questionnaire 
where we asked employees and business owners to evaluate selected areas in terms of quality, maturity and activity in the given areas. As a research sample, we chose companies from five European countries, namely Slovakia, the Czech Republic, Austria, Germany and Switzerland. Selected countries are geographically close and economically linked (for example, Slovakia, Germany). Slovakia and the Czech Republic are culturally similar, and Austria, Germany and Switzerland are more advanced economies. The aim of the research was to analyze and compare the readiness of enterprises from selected countries to Industry 4.0 from the viewpoint of the seven areas surveyed. 489 Slovak companies, 419 Czech companies, 220 Austrian, 187 German and 167 Swiss companies were analyzed within a research project during 2015-2018. The survey was taken in years 2015 and 2016. Differences between enterprises in the surveyed countries were analyzed using the Chi square test ( $\chi^{2}$ test) to identify statistically significant differences. $\chi^{2}=\sum_{i=1}^{n} \frac{\left(O_{i j}-E_{i j}\right)^{2}}{E_{i j}}$. Based on the nature of our variables (country comparison), non-parametric data analysis for categorical variables using Chi square test is appropriate for testing the significance of differences among sample groups. This statistical test was selected due to the aim of the article to compared and identify significant differences among countries surveyed. The level of significance was tested at $\mathrm{p}=0.05$ and $\mathrm{p}=0.01$. In the analysis of individual countries, we used descriptive statistics and evaluated the median, modus, standard deviation and coefficient of variation.

Research questionnaire was focused on the topic of company behavior and its links to the innovation performance. The respondents were mainly company owners or managers. The questionnaire was distributed directly to managerial contacts in the firms in order to secure the ability of the respondent to answer the questions while having all the necessary information in order to do so.

Research question used in the questionnaire was "Evaluate the environment of your organization in terms of quality, maturity and activity in the following areas":

- Internal system of education, knowledge management and development;

- Level of external partnerships in education and knowledge acquisition;

- Level of operational coordination - organization of projects, processes and tasks;

- Level of strategic alignment of development plans with existing resources;

- Availability of technologies and knowledge to develop new products / services;

- Corporate culture in relation to promoting innovation and knowledge development;

- Ability to identify and analyze trends, ability to respond to them.
Respondents responded on a scale of 1-5, 1 representing low / no quality, maturity and activity, 5 representing very high quality, maturity and activity.

These seven areas in organizations were selected based on Sammerl's innovation capability conception (Sammerl 2006), where she discusses the key dimensions that define the innovation capability of enterprises. The innovation capability based on the literature review in our article is the precondition to be able to do radical or incremental changes that drive businesses to sustaining competitiveness. As key business transformations within Industry 4.0 are also built on technologies, we have added two other dimensions that greatly influence companies' ability to innovate: the availability of technology and knowledge to develop new products / services and the ability to identify and analyze trends, the ability to respond to them.

\section{Results}

Table 1 shows the results of the analysis using descriptive statistics for individual groups of enterprises in the countries surveyed. Slovak companies reached the highest average rating of 3.62 on "Ability to identify and analyze trends, ability to respond to them". Most businesses rated above-average in this area, with assessment 4 - high quality, maturity and activity. Coefficient of variation was also the lowest in this area, $27 \%$. The second best-rated area for Slovak enterprises was "Corporate culture in terms of promoting innovation and knowledge development" with an average rating of 3.54, where enterprises rated this area most frequently with assessment 4 . In the other areas surveyed among Slovak enterprises, the 3 -average value was the most represented, with the lowest average score being in the "Level of external partnerships in education and knowledge acquisition" of 2.93. In this area, only $10 \%$ of Slovak businesses perceive very high quality, maturity and activity.

Czech companies were rated worse than Slovak businesses in all areas. The highest average score of 3.37 was achieved by Czech companies in two areas of "Availability of technologies and knowledge to develop new products / services" and "Ability to identify and analyze trends, ability to respond to them", with most businesses evaluating the area by assessment 3. In the case of "Corporate culture in terms of promoting innovation and knowledge development", the average rating was 3.33 , but most enterprises rated the area with assessment 4 . The average rating of less than 3 was similarly to that of Slovak companies in terms of "Level of external partnerships in education and knowledge acquisition" but also in the question of "Level of strategic alignment of development plans with existing resources".

Austrian companies achieved higher average ratings in almost all areas than Slovak and Czech companies. In contrast to these groups, the average ratings were very similar 
and ranged at 0.25 points. Austrian companies perceived the quality, maturity and activity most often above average (value 4), excluding the "Level of external partnerships in education and knowledge acquisition" and "Level of operational coordination - organization of projects, processes and tasks" where the average rating was 3 ). Deviations from the average rating were the lowest among all surveyed groups in the Austrian group.

In the case of German companies, the evaluation was higher in all areas compared to Slovak and Czech companies. In terms of evaluation structure, however, it was very similar to Slovak companies. German companies also perceived the best "Ability to identify and analyze trends, ability to respond to them", with an average rating of 3.67. Most businesses rated above-average in this area, with assessment 4 in quality, maturity and activity, with up to $25 \%$ evaluating the area 5-very high. The same average rating of 3.67 was also in the area of "Corporate culture in terms of promoting innovation and knowledge development". The lowest average score was in the "Level of external partnerships in education and knowledge acquisition", 3.11. In the "Internal system of education, knowledge management and development", the average rating was similar to that in Austria, but the distribution of responses was different. In Austria, more businesses rated 4 in comparison with 3 in Germany.

From the analysis of Swiss companies, the highest rating was again in "Ability to Identify and Analyze Trends, Ability to Respond to It" with an average score of 3.58 , followed by

Table 1. Results of statistical comparison of countries surveyed in selected areas (source: own processing)

\begin{tabular}{|c|c|c|c|c|c|}
\hline & & $\begin{array}{l}\text { Internal system of edu- } \\
\text { cation. knowledge manage- } \\
\text { ment and development }\end{array}$ & $\begin{array}{l}\text { Level of external partners- } \\
\text { hips in education and } \\
\text { knowledge acquisition }\end{array}$ & $\begin{array}{c}\text { Level of operational } \\
\text { coordination - organization } \\
\text { of projects. processes } \\
\text { and tasks }\end{array}$ & $\begin{array}{c}\text { Level of strategic alignment } \\
\text { of development plans with } \\
\text { existing resources }\end{array}$ \\
\hline \multirow{6}{*}{ 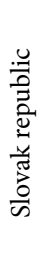 } & Average & 3.26 & 2.93 & 3.20 & 3.23 \\
\hline & Median & 4 & 3 & 3 & 3 \\
\hline & \begin{tabular}{|l|} 
Modus \\
\end{tabular} & 4 & 3 & 4 & 3 \\
\hline & \begin{tabular}{|l} 
Standard deviation \\
\end{tabular} & 0.989999839 & 1.094220242 & 1.07170574 & 1.02491463 \\
\hline & Coefficient of variation & $30 \%$ & $37 \%$ & $33 \%$ & $32 \%$ \\
\hline & Distribution & $-\square \square-$ & $-\square=$ & $-\square \square-$ & $-\square \square-$ \\
\hline \multirow{6}{*}{ 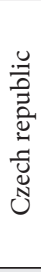 } & Average & 3.18 & 2.89 & 3.05 & 2.97 \\
\hline & Median & 3 & 3 & 3 & 3 \\
\hline & \begin{tabular}{|l|} 
Modus \\
\end{tabular} & 3 & 3 & 3 & 3 \\
\hline & \begin{tabular}{|l} 
Standard deviation \\
\end{tabular} & 1.129904623 & 1.10380249 & 1.141260734 & 1.102888727 \\
\hline & \begin{tabular}{|l|} 
Coefficient of variation \\
\end{tabular} & $36 \%$ & $38 \%$ & $37 \%$ & $37 \%$ \\
\hline & Distribution & $-\square \square=$ & $\square \square \square-$ & $\square \square-$ & $\square \square-$ \\
\hline \multirow{6}{*}{$\frac{\pi}{\underbrace{ \pm}}$} & Average & 3.44 & 3.23 & 3.40 & 3.40 \\
\hline & Median & 4 & 3 & 3 & 3 \\
\hline & \begin{tabular}{|l|} 
Modus \\
\end{tabular} & 4 & 3 & 3 & 4 \\
\hline & Standard deviation & 0.986520725 & 1.007195189 & 0.945804131 & 0.988560603 \\
\hline & Coefficient of variation & $29 \%$ & $31 \%$ & $28 \%$ & $29 \%$ \\
\hline & Distribution & $\square=$ & $-\square \square \square$ & $-\square \square-$ & $-\square \square-$ \\
\hline \multirow{6}{*}{$\widehat{\overparen{\Xi}}$} & Average & 3.43 & 3.11 & 3.29 & 3.39 \\
\hline & Median & 3 & 3 & 3 & 3 \\
\hline & \begin{tabular}{|l|} 
Modus \\
\end{tabular} & 3 & 3 & 3 & 4 \\
\hline & \begin{tabular}{|l|} 
Standard deviation \\
\end{tabular} & 1.151087375 & 1.132554168 & 1.045505832 & 1.008726827 \\
\hline & Coefficient of variation & $34 \%$ & $36 \%$ & $32 \%$ & $30 \%$ \\
\hline & Distribution & $\square \square \square \_-$ & $\square \square--$ & $-\square \square-$ & $-\square \square-$ \\
\hline \multirow{6}{*}{ 荵 } & Average & 3.52 & 3.16 & 3.31 & 3.31 \\
\hline & Median & 4 & 3 & 3 & 3 \\
\hline & Modus & 4 & 3 & 4 & 3 \\
\hline & Standard deviation & 0.989999839 & 1.094220242 & 1.07170574 & 1.02491463 \\
\hline & Coefficient of variation & $28 \%$ & $35 \%$ & $32 \%$ & $31 \%$ \\
\hline & Distribution & $\square \square \_$ & $-\square \square$ & $-\square \square-$ & $-\square \square-$ \\
\hline
\end{tabular}




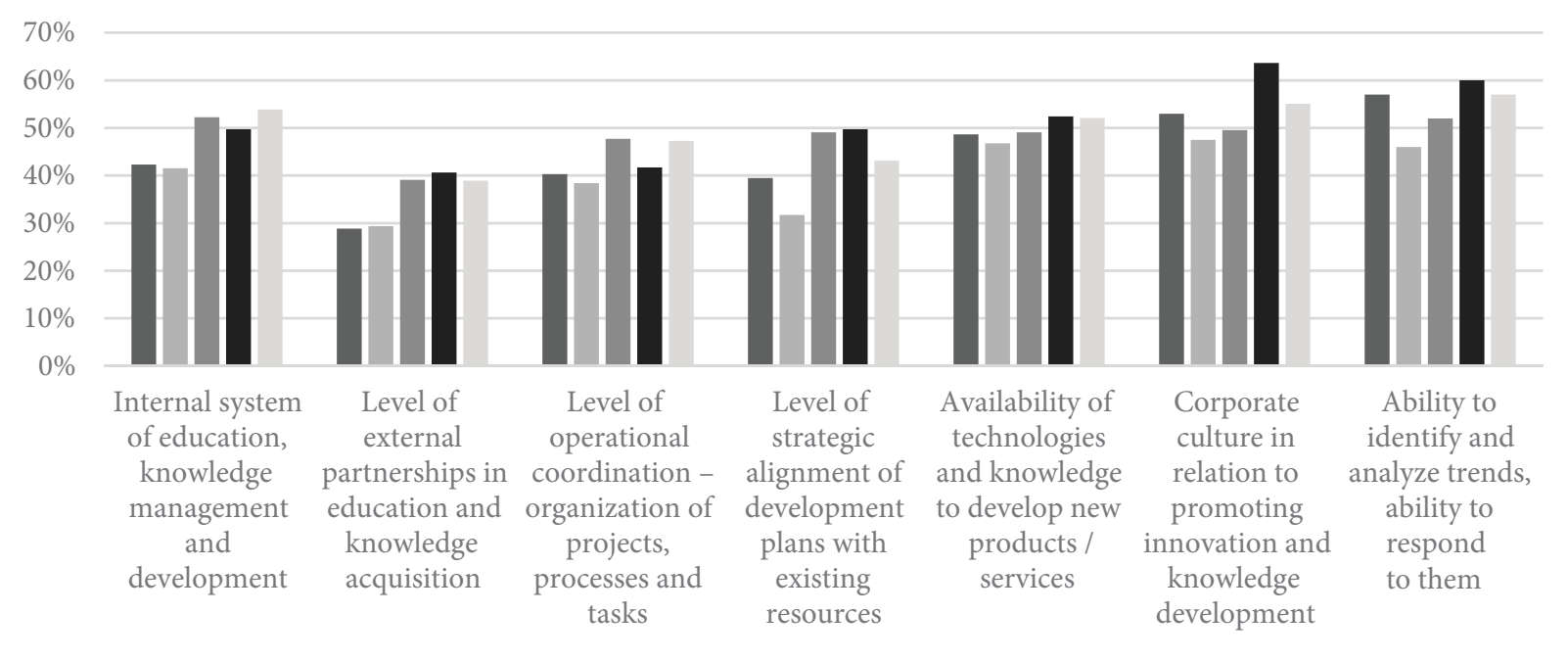

$\square \mathrm{SK} \square \mathrm{CZ} \square \mathrm{AT} \square \mathrm{DE} \backsim \mathrm{CH}$

Figure 1. Percentage comparison of companies from countries surveyed that assessed each are with value 4-5 (source: own processing)

"Internal System of Education, Knowledge Management and Development" with an average rating of 3.52, which is the highest among all countries surveyed. The lowest average rating was in the area of "Level of external partnerships in education and knowledge acquisition" of 3.16.

From this analysis it can be reviewed that all companies surveyed perceive their abilities to identify and analyze trends, the ability to respond to them very positively. On the contrary, the area of education in the form of external cooperation is perceived the weakest, but mainly the Slovak and Czech enterprises are lagging behind. Similarly, Slovak and Czech enterprises were also weaker in the area of internal education.

Subsequently, we looked at the comparison of the number of enterprises in each country that rated the area $4-5$, i.e. high to very high quality, maturity and activity. Figure 1 shows the percentages of enterprises. As in the case of a country-specific analysis, it can be observed that the highest ranking was achieved more frequently by firms from Austria, Germany and Switzerland than Slovakia and the Czech Republic on the issue of an internal education system and external partnerships in education. The Czech Republic achieved a high level of assessment for the level of strategic alignment only for $32 \%$ of enterprises, compared to $50 \%$ German companies. The most positive assessment was in corporate culture, where up to $64 \%$ of German businesses rated this area with a value of 4-5 to compare $47 \%$ of Czech enterprises.

A significant difference was found in the internal system of education between Slovak and Czech companies compared to Austrian companies (more than 10\%) and Slovak and Czech companies compared to Swiss companies (more than 12\%). In the case of the level of external partnerships, significant differences were found between Slovak and Czech companies compared to Austrian, German and
Swiss enterprises. It may be said that this is the weakest area to both countries, Slovakia and in the Czech Republic. Significant differences in the level of operational coordination were found only in the case of Czech companies compared to Austrian and Swiss companies. In the field of strategic alignment, the Czech companies were significantly less positive in ratings than Slovak companies. Slovakia is also significantly less positive in this area than Austria and Germany. No statistically significant differences were found regarding the availability of new technologies. An interesting area is corporate culture where Germany achieves the highest results most frequently and significantly more than Slovakia, Czech and Austria. In the last area of trends, there is a significant difference found only in the Czech Republic compared to Slovak, German and Swiss.

Based on Chi square test results we have identified significant differences. In rows in Table 2 are presented countries that assessed the area with positive assessment significantly more than companies from countries in columns.

Thus, it can be concluded that Slovak and Czech enterprises are assessed significantly weaker in the field of education, whether they are internal forms or external partnerships for education. The fact that Slovak and Czech companies do not involve in external partnerships for education support the results of study by Bialic Davendra. The study analyzing cluster activities shows, that common training and education are much less conducted in Slovak and Czech clusters than in Austrian (Bialic Davendra et al. 2014). Similarly, in the area of strategic alignment, both Slovak and Czech companies are significantly weaker. Interestingly, the Austrian, German and Swiss businesses are not significantly different in any area, which may also be due to the fact that they are stronger and more developed economies. The Czech Republic was rated weakest 
Table 2. Results of statistical comparison of countries surveyed in selected areas (source: own processing)

\begin{tabular}{|c|c|c|c|c|c|}
\hline & SK & $\mathrm{CZ}$ & $\mathrm{AT}$ & $\mathrm{DE}$ & $\mathrm{CH}$ \\
\hline $\begin{array}{l}\text { Internal system of education, knowledge manage- } \\
\text { ment and development }\end{array}$ & $\begin{aligned} \operatorname{AT}\left(\chi^{2}\right. & =6.049)^{\star} \\
\mathrm{CH}\left(\chi^{2}\right. & =6.715)^{\star *}\end{aligned}$ & $\begin{array}{l}\mathrm{AT}\left(\chi^{2}=6.724\right)^{\star *} \\
\mathrm{CH}\left(\chi^{2}=7.375\right)^{\star *}\end{array}$ & - & - & - \\
\hline $\begin{array}{l}\text { Level of external partnerships in education and } \\
\text { knowledge acquisition }\end{array}$ & $\begin{array}{l}\mathrm{AT}\left(\chi^{2}=7.333\right)^{\star *} \\
\mathrm{DE}\left(\chi^{2}=8.652\right)^{\star *} \\
\mathrm{CH}\left(\chi^{2}=5.881\right)^{\star}\end{array}$ & $\begin{array}{l}\mathrm{AT}\left(\chi^{2}=6.212\right)^{\star} \\
\mathrm{DE}\left(\chi^{2}=7.467\right)^{\star *} \\
\mathrm{CH}\left(\chi^{2}=5.015\right)^{\star}\end{array}$ & - & - & - \\
\hline $\begin{array}{l}\text { Level of operational coordination - organization } \\
\text { of projects, processes and tasks }\end{array}$ & - & $\begin{array}{l}\mathrm{AT}\left(\chi^{2}=3.894\right)^{\star} \\
\mathrm{CH}\left(\chi^{2}=5.137\right)^{\star}\end{array}$ & - & - & - \\
\hline $\begin{array}{l}\text { Level of strategic alignment of development plans } \\
\text { with existing resources }\end{array}$ & $\begin{array}{l}\operatorname{AT}\left(\chi^{2}=5.751\right)^{*} \\
\operatorname{DE}\left(\chi^{2}=5.839\right)^{*}\end{array}$ & $\begin{array}{c}\mathrm{SK}\left(\chi^{2}=5.853\right)^{\star} \\
\operatorname{AT}\left(\chi^{2}=18.483\right)^{\star *} \\
\mathrm{DE}\left(\chi^{2}=17.894\right)^{\star *} \\
\mathrm{CH}\left(\chi^{2}=6.789\right)^{\star *}\end{array}$ & - & - & - \\
\hline $\begin{array}{l}\text { Availability of technologies and knowledge to de- } \\
\text { velop new products / services }\end{array}$ & - & - & - & - & - \\
\hline $\begin{array}{l}\text { Corporate culture in relation to promoting inno- } \\
\text { vation and knowledge development }\end{array}$ & $\operatorname{DE}\left(\chi^{2}=6.246\right)^{*}$ & $\operatorname{DE}\left(\chi^{2}=13.51\right)^{\star *}$ & $\operatorname{DE}\left(\chi^{2}=8.146\right)^{\star *}$ & - & - \\
\hline $\begin{array}{l}\text { Ability to identify and analyze trends, ability to } \\
\text { respond to them }\end{array}$ & - & $\begin{array}{l}\operatorname{SK}\left(\chi^{2}=11.891\right)^{\star *} \\
\operatorname{DE}\left(\chi^{2}=10.588\right)^{\star *} \\
\mathrm{CH}\left(\chi^{2}=6.767\right)^{\star *}\end{array}$ & - & - & - \\
\hline
\end{tabular}

Statistical significance level ${ }^{\star} \mathrm{p}<0.05,{ }^{* *} \mathrm{p}<0.01$

in individual areas, but this may be partly influenced by the subjective stricter self-reflection of respondents, but in part the similarity of the results of the Slovak and Czech Republics can be observed. An important finding is that none of the countries surveyed significantly differentiated in the area of availability of technologies. This conclusion is not surprising since all the countries surveyed are industrially oriented, while according to World Bank Data, the share of industry (including construction) $\%$ of GDP is even higher in Slovakia and Czech Republic than in Austria, Germany or Switzerland (World Banka Data). The topic of technological change and the necessity of its adaptation is open in all countries surveyed, whether in a presentation at expert conferences, in the media, or in communicating the country's strategic plans where new technologies are part of it. Our results supports the Digital Intensity Index. According to Europe's Digital Progress Report 2017 and Digital Intensity Index (DII), Slovakia, Czech Republic and Germany are at very similar position in the percentage of very high/ high digitalization of enterprise, with the increase since 2010. The automatization and robot technology is also an important part of Industry 4.0 technology, especially for manufacturing businesses. According to OECD Science, Technology and Industry Scoreboard 2017, Czech Republic and Slovakia have similar industrial robot stock over manufacturing value added as Germany, while with steeper increase since 2005 then Germany and the value being higher then OECD average as well as EU average. The reason why technology availability is similarly perceived among the more advanced and less advanced countries in our sample is also the fact that Industry 4.0 is implemented to foreign subsidiaries through plants owned by companies already implementing these technologies, which is the case of Slovak or Czech subsidiaries with the head business in Germany (Smit et al. 2016).

\section{Conclusions}

The ability of enterprises to innovate and to make changes is determined by a number of internal and external factors. The external environment is currently favorable to investment and innovation activities. Economic stability and long-term economic growth have ensured an undisturbed environment with low interest rates and no major fluctuations in capital markets. At the same time, there is an intense debate on Industry 4.0. Most states in Europe have built their own strategic documents, with a rich expert discussions, and their set strategic goals are also institutionally supported. We are witnessing an increasing number of research articles on Industry 4.0.

Our research is dealing with the field of internal factors. The aim of our article was to assess the preparedness of enterprises for incoming changes and to identify the differences or common characteristics between the countries of the sample. Accordingly, we have identified some interesting findings. Germany is the main leader in the perception of the need and cultural predispositions for innovation. Almost in all the evaluated areas German companies achieved better results than other rated countries. They were significantly better than Slovakia, Czech and Austria in the question of corporate culture in terms of promoting innovation and knowledge development. 
Slovakia as a small and open economy, strongly economically linked to the German economy, achieves better ratings than the Czech sample. This is mainly in strategic areas, namely the question about ability to identify and to analyze trends and the second question about level of strategic alignment of development plans with existing resources. On the one hand, Slovak enterprises perceive the need to follow leaders in the sector to avoid losing their position. On the other hand, large companies operating in Slovakia are owned by foreign companies and thus implement changes coming from the headquarters environment. Consequently, the requirements for innovation and quality are passed on to their suppliers and subcontractors. In particular, the automotive and electrotechnical industry is at the forefront of the Slovak economy. Balanced results on the "Ability of technologies and knowledge to develop new products / services" are the result of the same issue being discussed in all countries. Companies have understood the importance of these technological changes, are interested in this issue, and thus feel the same preparedness for those changes. This may be a consequence of wider knowledge sharing at conferences and professional events taking place in the Central and Eastern European region. Local characteristics are most evident in the education system and knowledge acquisition from external partnerships where Slovak and Czech companies are still less open to engaging in external relations and also to support the education of their employees. Traditionally, in the Slovak and Czech economies, companies relied on a high-quality education system in the country and the staff coming from the schools trained. The low level of partnerships and the low ability to identify trends in enterprises in the Czech Republic lead to a significantly weaker strategic alignment of development plans with existing resources.

Our recommendation for making changes is to inspire countries to educate their employees and share knowledge through effective partnerships. This partnering in education can bring valuable information to businesses that want to take on the wave of innovation. Through partnerships, companies know more about the need for innovation and would be able to obtain alternative financial resources to realize the necessary investments in automation digitization and others.

\section{Limitations}

The limitation of our research is that in the given period, an external factors were not analyzed that could influence the economy in that particular period. For example, in view of the fact that the Czech Republic and Switzerland are not part of the Eurozone. The limit of our research is in the fact that it was a questionnaire research, to which it would be useful to add real data about the value of the investments in the given regions, as well as the qualitative nature of data could be supported with qualitative data which would allow us to realize more statistical analysis such regression. Another limitation of our study is in the research sample of Austrian, German and Swiss companies which is smaller compared to Slovak and Czech companies and is statistically representative only to the research sample. Slovak and Czech sample groups are statistically representative to the whole populations.

\section{Future research}

For the future research, we will want to examine the trends and time changes in companies' approach to innovation. We think that it is important to look at the issues of internal preparedness for the development towards industry 4.0, precisely because they will influence the actual results. In this context, we can also analyze attitudes expressed for example by our questions in relation to quantitative results. For example, an interesting relationship may be the weaker readiness of the Czech Republic found in our research, compared to the results of IFR 2018. In the Industrial Robot Report 2018, the International Federation of Robotics (IFR. ORG), Slovakia has installed by $21 \%$ more industrial robots per 10000 employees compared to the Czech Republic.

\section{References}

Alm E, Colliander N, Deforghe F, Lind F, Stohne V, Sundstrom O (2016) Digitizing Europer - Why Northern European frontrunners must drive digitization of the EU economy. The Boston Consulting Group http://image-src.bcg.com/ BCG-Digitizing-Europe-May-2016_tcm22-36552.pdf

Bendová A (2018) Odstraňujme plytvanie z konštrukcie. Uvolníme konštruktérov na kreatívnu prácu. SOVA Digital http://industry4.sk/magazin/digitalizacia/odstranujme-plytvanie-z-konstrukcie-uvolnime-konstrukterov-na-kreativnupracu/

Berger R (2014) Industry 4.0: The new industrial revolution, How Europe will succeed.

Bialic Davendra M, Pavelkova D, Vejmelkova E (2014) The cluster phenomenon in the selected Central European countries. Cambridge, UK: Cambridge Scholars Publishing.

Bohan M (2016) Next level: 9 Components of Industry 4.0 https:// news.heidelbergusa.com/2016/08/9componentsof4-0/

Častorál Z (2010) Strategic management of change and innovation. Praha: Comenius University of Praha.

Christensen CM (2006) The ongoing process of building a theory of disruption. Journal of Product Innovation Management 23: 39-55. https://doi.org/10.1111/j.1540-5885.2005.00180.x

Clearpath Team (2018) 5 Key Industry 4.0 Technologies https:// ottomotors.com/blog/5-industry-4-0-technologies

Connell J, Kriz A, Thorpe M (2014) Industry clusters: An antidote for knowledge sharing and collaborative innovation? Journal of Knowledge Management 18: 137-151. https://doi. org/10.1108/JKM-08-2013-0312 
Dalenogare L, Benitez G, Ayala N, Frank A (2018) The expected contribution of Industry 4.0 technologies for industrial performance. International Journal of Production Economics. https://doi.org/10.1016/j.ijpe.2018.08.019

Dávideková M, Mjartan M, Greguš M (2017) Implementing virtual reality into employee education in production sector of automotive industry: Creating worker training and assembling car dashboard in virtual reality. AD ALTA: Journal of interdisciplinary research 7 (1): 185-190.

Deloitte (2015) Industry 4.0: Challenges and solutions for the digital transformation and use of exponential Technologies. Zurich.

Deloitte (2017) The smart factory https://www2.deloitte.com/ insights/us/en/focus/industry-4-0/smart-factory-connectedmanufacturing.html\#

Herčko J, Štefánik A (2015) Components and principles of the Industry 4.0.

Hessman TM (2013) The dawn of the smart factory https://www. industryweek.com/technology/dawn-smart-factory?page $=1$

Hlušková T (2016) The Comparison of Industry 4.0 Strategies in Slovakia and in selected countries. Studia commercialia Bratislavensia 35 (3/2016), vol. 9 https://www.siemens.com/ customer-magazine/en/home/industry/one-step-closer-toindustrie-4-0/industrie-4-0-plant-design.html

Industry4 (2019) Digitization leads to Smart Factory http:// industry4.sk/o-industry-4-0/principy/

Ješko V (2016) The end of the rule of man: the fourth industrial revolution began https://tech.sme.sk/c/20422006/koniecvlady-cloveka-zacala-stvrta-priemyselna-revolucia.html

Kagermann H, Wahlster W, Helbig J (2013) Securing the Future of German Manufacturing Industry: Recommendations for Implementing the Strategic Initiative INDUSTRIE 4.0 Final Report of the Industrie 4.0 Working Group. Forschungsunion im Stifterverband fur die Deutsche Wirtschaft e.V., Berlin.

Kach A, Azadegan A, Wagner SM (2015) The influence of different knowledge workers on innovation strategy and product development performance in small and medium-sized enterprises. International Journal of Production Research 53: 2489-2505. https://doi.org/10.1080/00207543.2014.975856

KPMG (2016) The factory of the future: Industry 4.0- the challenges of tomorrow.
Lacko L' (2018) How are Slovak companies ready for Industry 4.0 https://www.pcrevue.sk/a/Ako-su-slovenske-firmy-pripravene-na-Industry-4-0

Lueth KL (2015) The top 5 new jobs created by the Industrial IoT https://iot-analytics.com/top-5-new-industrial-iot-jobs/

Mař́k V (2016) National initiative Industry 4.0. Praha.

Morone P, Taylor R (2004) Knowledge diffusion dynamics and network properties of face-to-face interactions. Journal of Evolutionary Economics 14 (3): 327-351. https://doi. org/10.1007/s00191-004-0211-2

Pajtinkova Bartakova G, Gubiniova K, Brtkova J, Hitka M (2017) Actual trends in recruitment process at small and mediumsized enterprises with the use of social networking. Economic Annals-XXI: 164 (3-4): 80-84. https://doi.org/10.21003/ ea.V164-18

Pease AF (2013) Industry 4.0. In: Visions, 8, 2013, n. 1, 3479 / 2005.

Prause G (2015) Industry 4.0: New perspectives for smart production and logistics in the Baltic Sea Region, Baltic Rim Economies (4): 41.

PWC (2016) Industry 4.0.: Industry 4.0: Building the digital enterprise https://www.pwc.com/sk/sk/publikacie/assets/2016/ceoprieskum/industry-4-0-budovanie-digitalneho-podniku.pdf

Rüßmann M, Lorenz M, Gerbert P, Waldner M, Justus J, Engel P, Harnisch M (2015) Industry 4.0: The future of productivity and growth in manufacturing industries. Boston Consulting Group, 9.

Sammerl N (2006) Innovations fähigkeit und nachhaltiger Wettbewerbsvorteil. Messung - Determinanten - Wirkungen. Wiesbaden, Germany: DUV.

Siemens (2016) "Industrie 4.0" in plant design.

Smit J, Kreutzer S, Moeller C, Carlber M (2016) Industry 4.0. European Parliament http://www.europarl.europa.eu/RegData/ etudes/STUD/2016/570007/IPOL_STU(2016)570007_EN.pdf

Stachová K, Papula J, Stacho Z, Kohnová L (2019) External partnerships in employee education and development as the key to facing Industry 4.0 challenges. Sustainability 11 (2): 345 . https://doi.org/10.3390/su11020345 